\section{Et hidtil ikke offentliggjort brev fra Weyse}

Af lektor, cand.mag. Jørgen Steen Larsen

“... den Idee at sanke Laurbær udenlands, har jeg for længe siden opgivet" 1

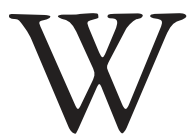
eyses udtalelse fra $1824 \mathrm{kan}$ passende stå som indledning til denne artikel og kontrast til det brev, som jeg hermed fremlægger.

For en snes år siden blev jeg tilfældigt og via Lauritz Nielsens brevregistrant ${ }^{2}$ opmærksom på et i Österreichische Nationalbibliothek bevaret brev fra Weyse til Tobias Haslinger ${ }^{3}$. Til trods for at brevet altså er registreret hos Lauritz Nielsen, er det mærkelig nok ikke medtaget i den iøvrigt omhyggelige udgivelse af Weyses breve.

Brevet kunne nok tåle en offentliggørelse. At denne artikel efter lang tids venten endelig kan foreligge, skyldes ikke mindst interesse og opmuntring fra lektor, dr. phil. Gorm Busk, hvem jeg skylder stor tak for værdifulde kommentarer og for hjælp med tydningen af vanskelige passager i brevet.

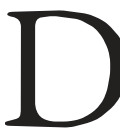

et er bemærkelsesværdigt, at Weyses tidligst trykte kompositioner udkom i udlandet. De VI Allegri di bravura (DF 140) blev således udgivet i 1796 af Schulz og Reichardt i Berlin og senere hos Nägeli i Zürich i 1803. Blandede Compositioner (DF 150) fra 1799 blev ganske vist trykt hos Sønnichsen i København, men også med tysk titel: Vermischte Compositionen. Weyses næste fire Allegri di bravura fra 1804 (DF 141) udkom 1809 hos Nägeli i Zürich, og Symfoni nr. 7 i Esdur (DF 123) fra 1799 udkom i Wien 1803 pa Bureau d'arts et d'Industrie.

Weyses komponistkarriere havde således fra begyndelsen et vist internationalt tilsnit, og anmeldelserne var positive, som det bl.a. kan ses $\mathrm{i}$ $\mathrm{AmZ}^{4}$. Weyses ambitioner om også at gøre operaerne og kirkemusikken kendt i udlandet, må derimod siges stort set at have slået fejls.

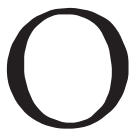

mkring 1820 synes det at være helt galt fat.

Af flere af de seks bevarede breve fra Breitkopf \& Härtel til Weyse fra tidsrummet 1810-1825 fremgår at Weyse gennem B\&H har forsøgt at få sine operaer opført i Tyskland. I B\&H's svarbrev dateret 5. marts 1819 citeres Leipzigs operadirektør for flere begrundelser for at afvise at opføre Ludlams Hule, bl.a. følgende "dass die Musik wenig dramatisch ist" 6

Dette var ikke den eneste ærgrelse Weyse skulle udsættes for på denne tid. Øjensynlig havde han medgivet Carl Maria von Weber, der i 1820 var i København, forskellige partiturer med det formål, at Weber skulle gøre musikken kendt i udlandet. Også dette forehavende synes kun at have bragt Weyse skuffelser?.

Næsten samtidig anmeldtes Ludlams Hule og Macbeth i Berliner Allgemeine musikalische Zeitung så dårligt, at Weyse følte sig foranlediget til at forsvare $\operatorname{sig}^{8}$. Intet under at Weyse på 
denne tid kun komponerede af pligt ${ }^{2}$. Skuffelsen og resignationen fremgår flere gange af det i artiklens begyndelse citerede brev fra december 1824 .

Endnu i juli 1829 er Weyse tilbageholdende med at forsøge at promovere sin egen musik i udlandet ${ }^{10}$.

Men så i august året efter skriver han følgende brev ${ }^{11}$ :

Copenhagen d 6 August 1830

Mit vielen Vergnügen habe ich von $\mathrm{Hr}$ Musikbändler Lose'2 vernommen, dass $E w$. Wohlgeboren geneigt sind einige von mir componierte Kirchenmusiken in Partitur herauszugeben. Ich nehme mir also hiermit die Freyheit Ihnen vorläufig den ambrosianischen Lobgesang ${ }^{13} z u$ übersenden, welchen ich einem vieljäbrigen Freund, dem Confer.th Brun ${ }^{14} z u$ dedicieren wünschte, da ich weiss, dass dem alten 84 jährigen Mann diese Aufmerksamkeit angenehm seyn wird. Vielleicht erhalten Sie von München aus noch eine zweite Composition von mir, eine

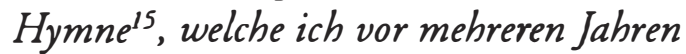
dem Kammermusicus Bärmann ${ }^{16}$ ubergab, damit sie dort aufgefiuhrt werde. So viel ich erfahren habe, ist aus der Auffuibrung bis jezt, noch nichts geworden (das Vorurtheil wider die ästhetischen Produkte des Nordens muss wohl unüberwindlich seyn,) also denke ich, $\mathrm{Hr} B$ wird wohl nichts dawider haben, dass ich meine Partitur mir wieder ausbitte. Sollten Sie bey der Herausgabe des ambr. Lobges. Ihre Rechnung finden, so stehen Ihnen mehrere meiner Arbeiten zu Dienste. Da es mir nicht sowobl darum zu thun ist, Schäze damit zu erwerben, als vielmehr nur sie dem Auslande bekannt zu machen, so werden wir über die Bedingungen leicht einig werden.
ergebenst
CE F Weyse
Professor und Ritter d.Dannebr. Ordens

\section{An Tobias Haslinger}

\section{Parentesen (Das Vorurtheil} wider ... ) forekommer ikke forhandlingstaktisk velovervejet, og er helt i pagt med Weyses resignation overfor udenlandsk berømmelse, men brevet viser dog alligevel et behjertet forsøg på at få musikken udbredt.

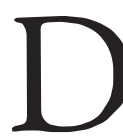
et afgørende vendepunkt for Weyse var, for mig at se, mødet med klavervirtuosen og komponisten Ignaz Moscheles, der i oktobernovember 1829 i to omgange gæstede København. Gensidig beundring og respekt synes at have præget forholdet mellem Weyse og Moscheles ${ }^{17}$. Ikke alene begyndte Weyse herefter af egen drift at komponere for klaveret ${ }^{18}$, han interesserede sig igen for udbredelse af sine værker i udlandet, således som nærværende brev viser.

Af de i brevet omtalte værker frembyder kun hymnen et problem. Kun to værker omtales af Weyse som hymner, nemlig Formalingshymnen (DF 19) slutdateret 27. august 1828 (med tekst af Høegh-Guldberg) samt Pinsehymnen (DF 14) slutdateret 3. maj 1820 (med tekst af Thaarup). 


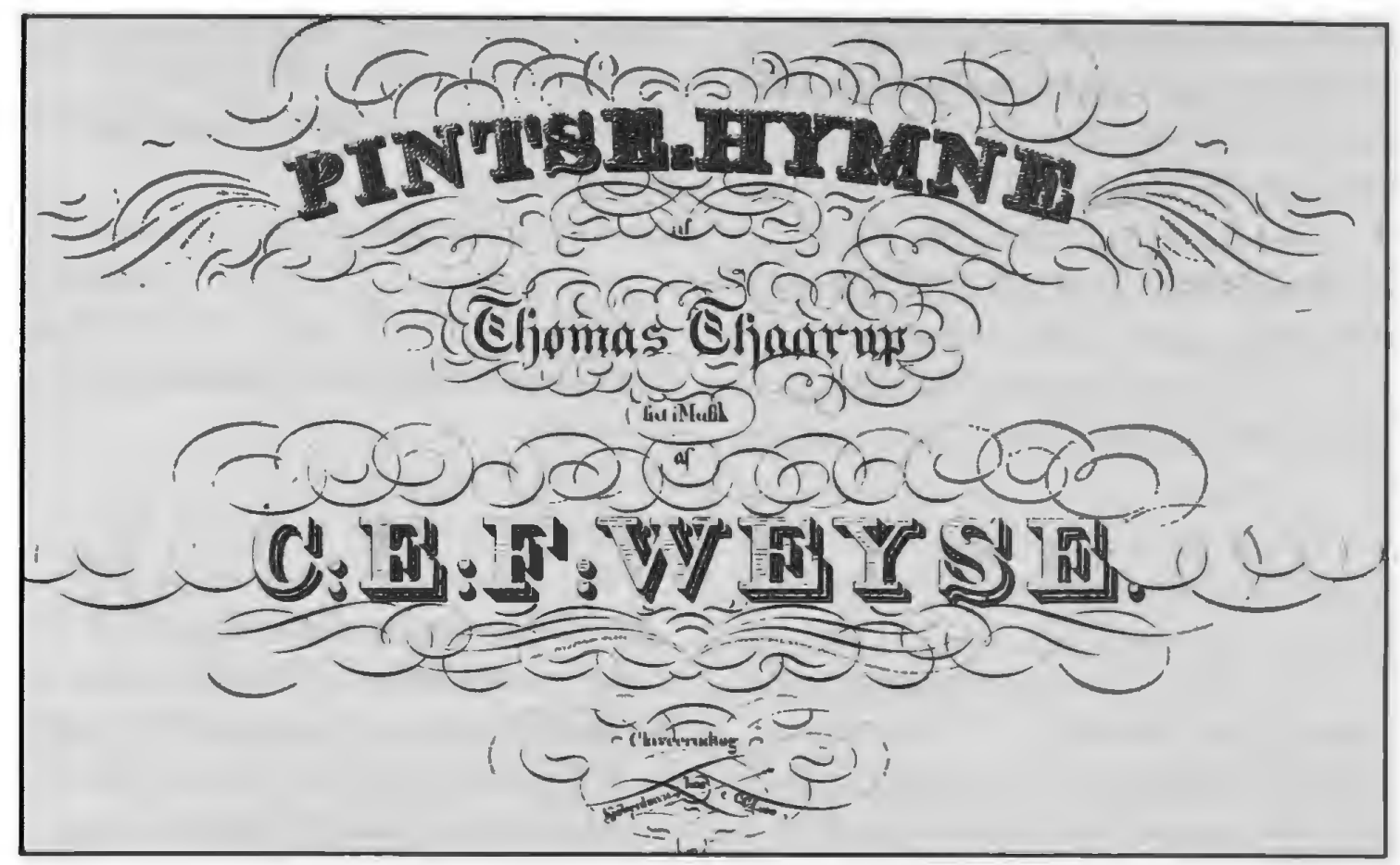

Pintsehymnen blev forsteopfort $i$ Trinitatis Kirke 21. maj 1820.

Det kunne have givet syn for sagn, hvis hymnen fandtes blandt Tobias Haslinger efterladte papirer. Dette lader dog desværre ikke til at være tilfældet ${ }^{19}$.

Eftersom Heinrich Bärmann var ansat som klarinettist ved hofkapellet i München, kunne man endelig tænke sig, at hymnepartituret eller evt. endnu et ukendt brev fra Weyse kunne befinde sig i Bayerische Staatsbibliothek, München. Men øjensynlig er dette heller ikke tilfældet ${ }^{20}$.

Selvom det således ikke kan dokumenteres præcis, hvilken hymne Weyse omtaler, forekommer det mig af flere grunde oplagt, at der er tale om Pinsebymnen.

Bärmann har formentlig forladt København allerede i april eller maj 1828, og det kan næppe tænkes, at han har gæstet København efter slutningen af august 1828, hvor Formalingshymnen blev færdigkomponeret, uden at afholde en koncert, der i så fald formentlig ville have været annonceret i Adresseavisen. Eller skulle Weyse efter færdiggørelsen af formælingshymnen (august 1828) have sendt partituret til Bärmann i München? Næppe! Ordet "übergab" antyder snarere en personlig overdragelse. I begge tilfælde forekommer det besynderligt at Weyse med henblik på en eventuel udgivelse skulle have foretrukket en musik med tekst så tydeligt bundet til en bestemt lejlighed ${ }^{21}$ frem for Pinsehymnen, hvis tekst indholdsmæssig er så generel, at den den netop ville være velegnet til oversættelse og udenlandsk udgivelse ${ }^{22}$.

At Weyse selv satte Pinsebymnen højt ${ }^{23}$ peger også på, at det er denne, der her er på tale.

Endelig kan næunes, at så sent 
som 8. maj 1839 opførtes af Weyse en hymne med tekst af Thaarup blandt andre værker ved en koncert i Vor Frue Kirke til fordel for Thorvaldsens museum $^{24}$, også her må det være pinsehymnen, der tales om. Et vidnesbyrd om pinsehymnens livskraft og styrke.

\section{Noter}

1 Sven Lunn og Erik Reitzel-Nielsen (udg.): C.E.F. Weyses breve I-II, Munksgaard, København 1964. (WB I og WB II). Her WB I, nr. 43.

2 Lauritz Nielsen: Registrant over Breve fra of til Danske i udenlandske Biblioteker. Levin \& Munksgaard, København 1934, s. 234.

3 Tobias Haslinger (1787-1842), musikforlægger. Videreforte fra 1826 som indehaver og under eget navn forlaget Bureau des Arts et d'lndustrie. Netop det forlag som i 1803 stod for udgivelsen af Weyses 7. symfoni.

4 f.eks. AmZ 1. Jahrg. nr. 35, 29/5 1799 sp. 547, 2. Jahrg. nr. 8 20/11 1799 sp. 151 154, 6. Jahrg. nr. 34, 23/5 1804 sp. $571-$ 573 og 12. Jahrg. nr. 3, 18/10 1809, sp. 47-48.

5 Dog tryktes ouverturerne til Faruk og til Ludlam Hule i 1817 hos B\&H.

6 Brev 5.marts 1819 fra B\&H til Weyse, $\mathrm{Ny}$ Kgl. Saml 3628, $4^{\circ}$.

7 WB II s. 99 og s. 325-27.

8 Aftrykt i A. P. Berggreen: C. E. F. Weyse's Biographie, Kjøbenhavn 1876, s.161-172.

9 WB I, nr. 42: "jeg componerer kun naar jeg bliver commandeert."

10 Se WB I, nr. 46.

11 Österreichische Nationalbibliothek, Musiksammlung, Handschriftensammlung 32/ 31-1.

12 C.C. Lose (1787-1835). Det er ikke lykkedes at efterspore denne forbindelse mellem Lose og Haslinger, men det er nærliggende at se en sammenhæng med den i 1831 på-
Tilbage står blot at bemærke at Weyses kirkemusik såvidt vides aldrig blev udgivet i udlandet, og at det ikke lader til, at Haslinger har svaret Weyse. I hvertfald findes et svarbrev øjensynlig ikke bevaret. begyndte udgivelse af Weyses kirkemusik på Loses forlag. ( c.f. Dan Fog: Kompositionen von C.E.F. Weyse, Dan Fog Musikverlag, Kopenhagen 1979, s 11.)

13 DF 18. Udgivelsen i 1831 skete i modsætning til de øvrige kirkemusikværker $i$ to udgaver. Klaverpartitur med dansk tekst og orkesterpartitur med tysk tekst.

14 Constantin Brun (1746-1836), gehejmekonferensråd. Bekostede i 1798 (1799 iflg. $\mathrm{DF}$, men det må være en fejl(?)) udgivelsen af 6 . symfoni og i 1832 tilegnede Weyse ham klaverudtoget af passions-kantaten (DF 13) (WB II, s. 75). Se WB I, nr. 52 og 56 for Weyses mere bramfrit åbenhjertige kommentarer om Brun.

15 Formentlig Pinse-Hymnen (DF 14).

16 Heinrich Joseph Bärmann (14/2 1784-11/ 6 1847). Klarinettist. Hans 9. koncertrejse indledtes 1827. Sammen med sønnen Carl besøgte han bl.a. Berlin, Nordtyskland, Danmark og Sverige (jvnf. MGG XV sp. 405). I Adresseavisen d. 29/3,31/3,2/4 og 4/4 1828 annonceres hans koncert på Det kgl. Teater d. $7 / 41828$ (iflg. venlig oplysning fra lektor dr. phil. Gorm Busk).

17 Nærmere redegørelse for relationerne mellem Weyse og Moscheles kan ses i s. 86-91 i Jørgen Steen Larsen: C.E.F. Weyses Klavermusik, speciale, Kbh. Universitet, 1976, mask.sk.. Se også Gorm Busk: Weyses Klavermusik, Dansk Arbog for musikforskning, XXIII 1995, København 1996.

18 Allegro di bravura op 50 (DF 142) fra 1829 tilegnet Moscheles, Etuder op. 51 (DF 143) fra 1831. 
19 Tobias Haslingers forlag blev overtaget af sønnen Carl H. ved Tobias H.'s død i 1842. En del af Carl Haslingers efterladte papirer (herunder formentlig autografe partiturer) findes i Archiv der Gesellschaft der Musikfreunde, Wien (Elskværdig oplysning af Elisabeth Wagner, Österreichishe Nationalbibliothek). Hos Gesellschaft der Musikfreunde findes imidlertid af Weyse kun trykte musikalier. (Efter venlig oplysning af Archivdirektor Dr. Otto Biba).

20 Således oplyser Anna Buchler, Handschriftenabteilung, Bayerische Staatsbibliothek, at biblioteket kun besidder et enkelt brev fra H. Bärmann (ikke til Weyse), og øjensynlig ingen til H. Bärmann.
21 c.f. WB II, nr. 434 og kommentarer hertil WB II s.299

22 Weyse omtaler (dog ikke med henblik på udenlandsk udgivelse) dette forhold i brev $16 / 121824$ til overhofmarskal A.W. Hauch, WB II, nr. 426.

23 c.f. Weyses omtale af arbejdet med den femstemmige fuga i pinsehymnen i et nu tabt brev til G.W. Fink (se WB II, s. 293).

24 AmZ 41. Jahrg. 1839 sp. 472. Meddeleren vil vende tilbage med videre omtale af den fortræffelige koncert. Men det sker ikke. I hvert fald ikke i løbet af bladets 41. årgang. 